Nietbayeva $G . B^{l}$, Kulzhabayeva $S . F^{l}$

${ }^{1}$ Kazakh national pedagogical University named after Abai

Almaty, Kazakhstan

\title{
SOME ASPECTS OF PSYCHOLOGICAL CHARACTERISTICS OF MEDIATION STUDENTS
}

\section{Annotation}

This article will examine the basic views on the psychological characteristics of students-psychologists studying in the field of "mediation." The main concepts will be considered: personality traits, neurodynamic features and their stress resistance.

Keywords:mediation, higher education, personality, neurodynamic properties, stress resistance.

Ниетбаева Г.Б ${ }^{1}$, Ұллжабаева С. $\Phi^{1}$

Абай атындавы Қазақ ұлтық педагогикалық университеті

Алматы, Қазақстан

\section{МЕДИАТОР СТУДЕНТТЕРДІН ПСИХОЛОГИЯЛЫҚ ЕРЕКШЕЛІКТЕРІНІН КЕЙБІР ҚЫРЛАРЫ}

\section{Түйіндеме}

Бұл мақалада «медиация» бағыты бойынша оқитын психология студенттерінің психологиялық сипаттамалары туралы негізгі пікірлер қарастырылады. Негізгі ұғымдар қарастырылатын болады: тұлғалық ерекшеліктер, нейродинамикалық ерекшеліктер және олардың стресске тұрақтылығы. Tүйін сөздер: медиация, жоғары білім, тұлға, нейродинамикалық қасиеттер, стресске тұрақтылығы.

\author{
Ниетбаева Г.Б ${ }^{1}$,Кулжсабаева С. $\Phi^{1}$ \\ ${ }^{1}$ Казахский национальный педагогический университет имени Абая \\ Алматы, Казахстан
}

\section{НЕКОТОРЫЕ АСПЕКТЫ ПСИХОЛОГИЧЕСКИХ ОСОБЕННОСТЕЙ СТУДЕНТОВ МЕДИАТОРОВ}

\begin{abstract}
Аннотаиия
В данной статье будут рассмотрены основные воззрения на психологические особенности студентов-психологов, обучающихся по направлению «медиация». В качестве основных понятий будут рассмотрены: личностные особенности, нейродинамические особенности и их стрессоустойчивость.
\end{abstract}

Ключевые слова: медиация, высшее образование, личность, нейродинамические свойства, стрессоустойчивость.

Currently, students are very important and diverse social groups. The development of specialists is one of the main tasks set by the Head of state in the education system. Every successful and competitive specialist was once a student. The use of psychological and pedagogical methods of working with students is an important basis for promising and effective interaction between teachers and students. Each student chooses their profession based on a number of personality traits, views, potential prospects, and many other factors [1]. Based on this formulation, we can say that at the beginning and beginning of training in one specialty, the student has the initial parameters of training in it. 
As a result, educational activities can affect the development of the student's personality. The educational process itself is complicated for the education and formation of the necessary professional skills and competencies of a person who directly affects the student's personality [2].

In order to consider the personality of a student mediator, it is necessary first to study the main component of regulating his behavior-the neurodynamic features of nervous processes. Of course, neurodynamic signs are the basis of the nervous system, which differ from the usual idea of the properties of the nervous system: the properties of the nervous system, according to I. p. Pavlov, were or are not severe. This concept is clearly manifested in the classification of types of the nervous system of I. p. Pavlov, in which he distinguishes the inertia of the properties of the power, speed-unbalanced, mobile nervous system. The peculiarity of this classification is its lack of rigidity. Later, this formulation did heat stresses eco-friendly, V. D. Nebylitsyn [3].

In accordance with the concept of neurodynamic features of the processes of the nervous system, a certain stereotype has been formed, according to which a psychologist needs a strong nervous system. This is especially true for psychological specialists, their work in the field of conflict situations and law. in our case, mediators. The basis for forming this approach is that a weak nervous system can not withstand high transcendental inhibition and quickly gets tired, deprives a person of the opportunity to fully participate in the action. This representation can be considered erroneous. Indeed, the strength of neural processes determines the energy potential of the body, shows the extreme possibilities of its concentration, but the professional activity of the mediator is a complex structural phenomenon in which neurodynamic features do not play an important role. These data are confirmed by etc. Teplov, who proved that neurodynamic features affect the style of action, but in no case its success [4].

Therefore, neurodynamic features may affect the future professional activity of the student mediator, but this effect occurs in the field of choosing the style of independent work and does not affect the success of the performance.

Along with neurodynamic features, there are also personal qualities that are important for the professional activity of the mediator. Among them are: anxiety, communication, stress resistance, flexibility of thinking, and others.

Personal qualities really have an important role in professional activity. Personal qualities can determine the features of interaction with clients, especially conflicts, decision of communication styles, and others. In the structure of personal qualities that are important for professional activity, they distinguish their abilities, enthusiasm and character [1].

Abilities are an important component of any activity that determines its success. Opportunities are not only what was originally given, but also the development of the guiding action, the packaging. The development of students ' abilities is largely the result of knowledge. The development of personal abilities in higher education becomes mandatory [5].

Personal abilities are found in all areas of activity. The mediation process is a very complex set of stages that require certain skills. The example can be aligned with the following steps (the steps are irregular and are only used as an example):

1) Preparatory stage. At the preparatory stage of mediation, you need to show your organizational skills.

2) Preface. At this stage, the communicative abilities of the mediator's personality, the ability to create an atmosphere of the mediation process for its participants and offer themselves as a specialist come to the fore.

3)development of proposals. In this case, the mediator must demonstrate his well-known leadership, organizational, and communicative personal qualities. In addition, it shows the analytical and synthesizing sides of thinking, participating directly in the process [6].

As you can see, the requirements for the mediator's abilities are different and may change depending on the individual characteristics of the participants in the mediation process.

Resistance to stress is one of the main qualities of a mediator and a profession focused on any other subject.

G. Selye proposed a step-by-step classification of the stress period. He identified three stages of stress: the anxiety phase, the resistance phase, and the exhaustion phase.

A period of anxiety is the first reaction to stress. There is a mobilization of the body's resources, and the person feels preoccupied, which is called the phase.

The resistance phase is characterized by the maximum level of protection of the body from stress. The resources spent are discarded for depression or removal of stress. If this period is too long, or if stress causes you to collect too much of your body's resources, the next stage begins. A phase of exhaustion. At 
this time, the body had spent too many resources to get rid of stress, and now there were no necessary resources for it. It is here that there are pronounced manifestations of the General adaptation syndrome (stomach ulcer, thymus reduction, adrenal enlargement) [7].

The overall goal is to keep the stress response in the resistance phase. If we allow the development of stress and its transition to a chronic basis, it can be accompanied by a set of undesirable syndromes for the individual: from frequent situational anxiety, ending in a violation of its mental compatibility and presenting a potential danger of disease [8].

To sum up, it is impossible to live without stress, but it is the main link in its management. Excessive stress makes you incapable. Your ability to handle stress affect the manifestation of all other individual characteristics. Because stress tolerance is one of the most important factors. The development of antistress stability should become one of the priority directions in the training of mediation students. There are also many exercises that can help a person resist stress or help them temporarily overcome a stressful situation. Example: morning exercises, meditation, rational goal setting, etc. [9]

\section{Conclusion}

Students of meditation go through very difficult exercises. The specifics of their professional activities are based on a high level of requirements for them. Among them, professional personal qualities differ, such as responsibility, sociability, flexibility of thinking, etc. A person's resistance to stress is also very important. Weak stress resistance can harm the entire person, no matter how much it develops. This not only strengthens existing problems, but also causes a negative image adopted by others, which leads to a violation of interpersonal relationships. Therefore, the development of anti-stress resistance in students is an important factor in their future successful professional activities.

\section{Literature review}

1. Ilyin E. p. Work and personality. Workaholism, perfectionism, laziness. - Saint Petersburg: Piter, 2011, $380 p$.

2. Educational psychology. Textbook. // Ed. Orlova A., Regush L.-Saint Petersburg: Peter, 2016, $416 p$.

3. Ilyin E. p. Psychology of individual differences. - Saint Petersburg: Piter, 2011, 1270 p. Teplov B. M. Selected works. 2 vol. - Moscow: Pedagogika, 1985.

4. Volkova E. V. Psychology of special abilities: differential-integration approach. Moscow, 2011.

5. The seraliev M. A. Fundamentals of mediation. Textbook. - Almaty: Almanac, 2017, 133 p.

6. Selye G. Stress without distress-M.: "Progress", 1982.

7. Pre-Painful conditions and borderline mental disorders (etiology, pathogenesis, specific and nonspecific symptoms, therapy). - Moscow: Littera, 2010.

8. Scherbatykh Yu. V. "Psychology of stress", Moscow, 2005. 